\title{
Cholesterol Assimilation of Saccharomyces cerevisiae B-18 isolated from gastrointestinal tract of Javanese duck
}

\author{
L. Istiqomah*, M. Anwar, A.S. Anggraeni and E. Damayanti \\ Research Center for Natural Product Technology (BPTBA), Indonesian Institute of Sciences (LIPI), \\ Gading, Playen, Gunungkidul, D.I. Yogyakarta - Indonesia. \\ *Corresponding E-mail: lusty.istiqomah@gmail.com
}

Received September 28, 2017; Accepted April 16, 2018

\begin{abstract}
ABSTRAK
Penelitian ini bertujuan untuk mengetahui khamir yang berpotensi dalam mengasimilasi kolesterol dan mengetahui aktivitas enzim Bile Salt Hydrolase (BSH) secara in vitro menggunakan media Chloramphenicol Yeast Glucose (CYG) yang disuplementasi $\mathrm{CaCl}_{2}$ dan Taurodeoxycholic Acid (TDCA). Isolat khamir dikoleksi dari saluran pencernaan ayam kampung asli Indonesia (Gallus javanicus), bebek (Anas javanicus), dan mentok (Anas moschata). Uji Bile Salt Hydrolase (BSH) dilakukan untuk mengetahui adanya sekresi BSH dari strain khamir untuk mengkonjugasi garam empedu menjadi asam kolik bebas dengan cara mengukur zona presipitasi pada medium spesifik. Pengukuran kemampuan mengasimilasi kolesterol secara kuantitatif menggunakan media CYG broth mengandung kolesterol terlarut $(500 \mathrm{ppm})$ dan diinkubasi pada suhu $30^{\circ} \mathrm{C}$ selama $72 \mathrm{jam}$. Kandungan kolesterol pada supernatan dianalisis menggunakan microplate reader. Analisis data menggunakan Rancangan Acak Lengkap (RAL) pola searah. Zona presipitasi yang terbentuk tidak berbeda nyata antar isolat khamir $(\mathrm{P}>0,05)$. Isolat $\mathrm{B}-18$ yang diisolasi dari bebek menghasilkan persentase tertinggi kolesterol terasimilasi $(51,83 \%)$ dan isolat tersebut teridentifikasi sebagai $S$. accharomyces cerevisiae ( $S$. cerevisiae). Berdasarkan analisis pohon filogeni, isolat B-18 memiliki hubungan kekerabatan dengan S. cerevisiae mt 21s (nomor aksesi X00149.1). Dari hasil tersebut dapat disimpulkan bahwa $S$. cerevisiae B-18 berpotensi mengasimilasi kolesterol secara in vitro.
\end{abstract}

Kata kunci: khamir, bile salt hydrolase (BSH), asimilasi, kolesterol, bebek

\begin{abstract}
This study had a purpose of obtaining potential indigenous yeasts for assimilating cholesterol and assessed the in vitro activity of Bile Salt Hydrolase (BSH) using Chloramphenicol Yeast Glucose (CYG) media supplemented $\mathrm{CaCl}_{2}$ and Taurodeoxycholic Acid (TDCA). Yeasts were collected from the gastrointestinal tract of Indonesian native chicken (Gallus javanicus), Javanese duck (Anas javanicus), and Muscovy duck (Anas moschata). The BSH assay was performed to determine secretion of BSH from yeast strain to conjugate bile salts into cholic acid-free by measuring precipitation zone in a specific medium. The quantitative measurement to assimilate cholesterol in yeast using CYG broth contained soluble cholesterol $(500 \mathrm{ppm})$ and incubated at $30^{\circ} \mathrm{C}$ for 72 hours. Microplate reader used to analyze cholesterol content in the supernatant. Data were analyzed using Analysis of Variance (ANOVA) with one way completely randomized. Precipitation zone found among isolates did not significantly different $(\mathrm{P}>0.05)$. Isolate $\mathrm{B}-18$ from Javanese duck performed the highest percentage of assimilating cholesterol with the value of $51.83 \%$ and identified as $S$. cerevisiae. This isolate was closely related to $S$. cerevisiae mt 21s (accession number X00149.1) based on phylogenetic tree analysis. It could be
\end{abstract}


concluded that $S$. cerevisiae B-18 was potential for assimilating cholesterol in vitro.

Keywords: yeast, bile salt hydrolase (BSH), assimilation, cholesterol, Javanese duck

\section{INTRODUCTION}

Broiler chicken meat demands in a community are a lot because of fine texture and soft but between the rough fibers of meat is easy to accumulate fat. Wang et al. (2009) record $20 \%$ carcass fat in contemporary chickens. Choe et al. (2010) reported that crude fat in thigh meat of Korean native chicken was lower $(2.53 \%)$ than commercial broiler $(4.74 \%)$. The fat and cholesterol content in thigh meat of two indigenous Thai strains Black-Boned's meat and Thai native's meat were lower than the imported breed, Rhode Island Red (Jaturashita et al., 2008). Lawrie (1998) reported that pursued in selection for growth and fat retention with associated to increase of deposition cholesterol might be the reasons for lower contents of cholesterol and fat meat on two indigenous Thai. Cholesterol levels in broiler chickens are highly accumulated in blood. Broiler chickens contain meat cholesterol and abdominal fat content around $2.56 \%$ with the highest content in skinless meat ranging between $133-202 \mathrm{mg} / 100 \mathrm{~g}$, whole meat around 261-407 $\mathrm{mg} / 100 \mathrm{~g}$, while the cholesterol content in the native chicken breast was $177.47 \mathrm{mg} / 100 \mathrm{~g}$, and thighs was $187.95 \mathrm{mg} / 100 \mathrm{~g}$ (Ismoyowati and Widiyastuti, 2003). Due to the high cholesterol content in meat, the importance of functional natural materials in poultry diets has increased attention in recent years. Probiotic is one of a natural feed additive used for this purpose.

Probiotic was defined as live microorganisms that confer a health status on the host when given in adequate amounts (FAO/WHO, 2002) such as yeast, some $S$. cerevisiae strains and $S$. boulardii (Tomičić et al., 2016). Cholesterol assimilation of probiotic yeasts had been a focus of several researchers in recent years (Psomas et al., 2003; Chen et al., 2010). Several studies reported that yeasts could eliminate cholesterol in vitro. Several yeasts have been investigating for their potential to assimilate cholesterol excluding for Saccharomyces cerevisiae, Pichia kudriavzevii, and Kluyveromyces lactis (Psomas et al., 2003). Afriani (2003) reported that cholesterol content in broilers meat with addition probiotic Bacillus $s p$. $(83.83 \mathrm{mg} / 100 \mathrm{~mL}$ plasma) or $S$. cerevisiae $(82.50$ $\mathrm{mg} / 100 \mathrm{~mL}$ plasma) was lower than control that received antibiotics $(109.33 \mathrm{mg} / 100 \mathrm{~mL}$ plasma). According to Chen et al. (2010), some potential probiotics isolated from cow raw milk such as $P$. kudriavzevii BY10, P. kudriavzevii BY15, P. fermentans BY5, and Yarrowia lipolytica HY4 had an ability for assimilating cholesterol in the human intestine after 72 hours of incubation.

This study was conducted to obtain potential indigenous yeasts isolated from the gastrointestinal tract of poultry as the potential probiotic for assimilating cholesterol with in vitro assay and Bile Salt Hydrolase activity.

\section{MATERIALS AND METHODS}

\section{Isolation and Identification of Yeast}

Yeast strains were isolated from the gastrointestinal tract of native Indonesian chicken (Gallus javanicus), Javanese duck (Anas javanicus), and Muscovy duck (Anas moschata) according to Al-Shimmery (2011) method. Small intestine, cecum, and colon were cut, and the contents of lumen were taken and then diluted in $\mathrm{NaCl}$ solution (Merck) $0.85 \%$ up to $10^{5}$ dilutions. Chloramphenicol Yeast Glucose (CYG) agar media (Oxoid) with $\mathrm{pH} 6.2$ was plated and incubated for $48 \mathrm{~h}$ at $30^{\circ} \mathrm{C}$ with the addition of each serial dilution. Yeast isolates were grown in CYG broth contained $15 \%$ glycerol (v/v) and kept in frozen condition $\left(-80^{\circ} \mathrm{C}\right)$. Yeast isolate was streaked on CYG agar plate to guarantee purity for any assay.

The identification of selected yeast isolate was performed molecularly based on partial genetic analysis in the ribosomal DNAD1 / D2 Large Sub Units (LSU) region. The analysis was performed with PCR colonies. DNA extraction was done by the boiling method at $98^{\circ} \mathrm{C}$. The extracted DNA was amplified using a PCR machine. The procession of $600 \mathrm{bp} \mathrm{D} 1 / \mathrm{D} 2$ region LSU rDNA using Go Taq Green Master mix and NL1 primer: 5'-CATATCAATAAGCGGAGGAA AG-3' and NL4 primer: 5'-GTCCGTGT TTCAAGACGG-3 on $\mathrm{Ta} 55^{\circ} \mathrm{C}$ optimization for 30 cycles.

The PCR product was purified by the method of PEG precipitation (Arbeli and Fuentes, 2007), then followed with sequencing cycle. The 
sequencing cycle results were regrouped by purification method with ethanol. The nitrogen base sequence analysis was examined by an automated DNA sequencer (Applied Biosystems).

The next sequenced trimming and assembling data using the ChromasPro 1.7.5 program. Sequence data (Fasta) that had been assembled in BLAST next to genomic data that registered in DNA Data Bank of Japan/DDBJ (http://blast.ddbj.nig.ac.jp/). BLAST results having a molecular level of homologous status determine the name of the taxon/sample species (Kurtzman and Robnett, 1998). Phylogenetic analysis was accomplished by comparing several sequences with high similarity in BLAST result. The statistical method used was Maximumlikelihood. Stability of grouping was measured using 1000 bootstrap replicates. The phylogenetic tree was performed by a MEGA5 program (Cobos et al., 2011).

\section{Lyophilisation}

One-milliliter yeast suspensions were placed in sterile tubes and centrifuged using Centofriger ${ }^{\circledR}$ BL II (Selecta) at $2.600 \mathrm{~g}$ for 10 min (Cheong et al., 2008). The yeast cells then washed and centrifuged in $1 \mathrm{~mL}$ sterile paper points (PPs). The pellet was dissolved in $1 \mathrm{~mL}$ of low-fat milk powder $(120 \mathrm{~g} / \mathrm{L})$ added with trehalose $(70 \mathrm{~g} / \mathrm{L})($ Sigma-Aldrich) in sterile water solution. The suspension of yeast-milk $(0.2 \mathrm{~mL})$ then put into sterile cryotubes and lyophilized for $3 \mathrm{~h}$ using freeze dryer $\left(-58^{\circ} \mathrm{C}\right)$. After drying process, the cryotubes were kept at $4{ }^{\circ} \mathrm{C}$.

\section{Plate Assay of Bile Salts Deconjugation Activity}

The deconjugate bile salts activity of yeast was evaluated according to Begley et al. (2006) method with modification. Soft $\mathrm{CYG}$ agar $(\mathrm{pH}$ 5.6; Oxoid) was added with $0.5 \%$ sodium salt of Taurodeoxycholic Acid/TDCA (w/v) (Sigma) and $0.37 \mathrm{~g} / \mathrm{L} \mathrm{CaCl}_{2}$ (Merck). The assay by being impregnation yeasts around sterilized paper disks (Oxoid) on the $\mathrm{CYG}$ agar incubated at $30^{\circ} \mathrm{C}$ for 72 hours under anaerobic atmosphere condition. The positive BSH activity of yeast isolates was indicated by bile acid precipitation surround the yeast colonies/opaque halo (Sourabh et al., 2015). Results were analyzed by measuring the diameters of precipitation zone. Yeast isolates grown on CYG agar without TDCA and $\mathrm{CaCl}_{2}$ were used as the negative control. Measurements were repeated three times.

\section{Cholesterol Assimilation Activity}

The capability of yeast strains for cholesterol assimilation in CYG broth was investigated by using water-soluble cholesterol. Cholesterol (C75209, Sigma) in Tween 80 were added to CYG broth at a final concentration $500 \mathrm{ppm}$. An overnight culture $(1 \%, v / v)$, was put into CYGcholesterol solution and incubated at $30^{\circ} \mathrm{C}$ for 72 $\mathrm{h}$. The culture suspensions then centrifuged at $4000 \mathrm{rpm}$ at $4^{\circ} \mathrm{C}$ for $10 \mathrm{~min}$ and the supernatants contained non-assimilated cholesterol was collected. The viability of yeast was evaluated by Total Plate Count (TPC) methods.

Water-soluble cholesterol was determined by following Gilliland et al. (1985) method. Onemilliliter absolute ethanol and $500 \mu \mathrm{L}$ of methanolic potassium hydroxide $(33 \%$, w/v) were added to $500 \mu \mathrm{L}$ samples, mixed for 1 min with vortex and incubated for $15 \mathrm{~min}$ at $37^{\circ} \mathrm{C}$. Onemilliliter of distilled water and $1.5 \mathrm{~mL}$ of hexanes were added to the cooling solutions and the vortex mixed was repeated for $1 \mathrm{~min}$. The hexane layer was moved into a clean test tube then evaporated by flowing nitrogen gas at $60^{\circ} \mathrm{C}$. One-milliliter ophthalaldehyde $(50 \mathrm{mg} / \mathrm{dL})$ in acetic acid was mixed with the dried sample. After incubation for $10 \mathrm{~min}$, the sample was mixed with $250 \mu \mathrm{L}$ concentrated sulfuric acids $\left(\mathrm{H}_{2} \mathrm{SO}_{4}\right)$. The sample solution was read at $570 \mathrm{~nm}$ to determine the concentration of cholesterol.

Standard cholesterol $(99 \%$ standard for chromatography; Sigma) were used in the concentration $0,4,8,12,16,24,32,40,52,64$, $128,256 \mathrm{ppm}$. Cholesterol assimilated by yeast was calculated following the equation (TomaroDuchesneau et al., 2014):

Cholesterol assimilated $(\mathrm{ppm})=[$ cholesterol $\left.(\mathrm{ppm})]_{0 \mathrm{~h}}-[\text { cholesterol }(\mathrm{ppm})]_{72 \mathrm{~h}}\right]$.

Cholesterol-lowering percentage of yeast was evaluated as follow:

Cholesterol assimilated $=[$ cholesterol assimilated $(\mathrm{ppm}) /$ cholesterol $\left.(\mathrm{ppm})_{0 \mathrm{~h}}\right] \times 100 \%$... (2)

\section{Data Analysis}

The data of precipitation zone in BSH activity assay and the percentage of assimilating cholesterol in vitro were analyzed using Analysis of Variance (ANOVA) with one way completely randomized design and the differences between treatments mean were evaluated with Duncan's Multiple Range Test (Gomez and Gomez, 2007). The statistical analysis was conducted by Costat 
(Cohort, 2008).

\section{RESULT AND DISCUSSION}

\section{Isolation of Yeast from Poultry Gastrointestinal Tract}

Isolation result showed that there were 112 of isolates predicted as yeast based on morphological appearance (31 isolates from native chicken, 20 isolates from Javanese duck, and 61 isolates from Muscovy duck). AlShimmery (2011) reported that 58 yeast isolated from intestinal tracts birds dominated by Saccharomyces (31.03\%), followed by Candida glabrata, C. tropicalis, C. albicans, C. fmata and Creptococcus neoformans. The most commonly isolated species from oral cavity and crop of bird were Candida albicans (32.5\%), followed by $C$. tropicalis, Trichosporon asteroides, C. famata and others (Brilhante et al., 2010). Abbas et al. (2017) also reported that 100 mycological isolates from systemic infection of dropping birds (pigeon, pet bird, and chicken) were classified into (25\%) yeasts and $(63 \%)$ molds.

Yeast is a single-celled fungal eukaryote. Their ability in fermenting sugars in the lack of oxygen to produce carbon dioxide made the yeast widely used in various industries (Roto et al., 2015). Yeasts generate several metabolites include carotenoids, amino acids, enzymes, vitamin, and some miscellaneous products (Roto et al., 2015).

\section{Bile Salt Deconjugation Activity}

Yeast isolates with a capability to deconjugate bile salts were determined using CYG media supplemented with $\mathrm{CaCl}_{2}$ and TDCA. The sodium taurodeoxycholate salt acts as a substrate to be conjugated by $\mathrm{BSH}$ from yeast while the addition of $\mathrm{CaCl}_{2}$ ions was intended to optimize the work of the BSH activity. A positive result of deconjugation activity was considered from the formation of opaque halo (precipitated bile acid) around colonies (Lim et al., 2004; Sourabh et al., 2015). Among 112 isolates tested, there were 104 isolates (28 isolates from native chicken, 19 isolates from Javanese duck, and 57 isolates from Muscovy duck) had the precipitation zones (Figure 1). Among 104 isolates, there were 4 isolates with the largest diameter of precipitation zones (Data not shown). Different diameters of precipitation zones with high $\mathrm{BSH}$ activity from 4 isolates are presented in Table 1. Data showed that the isolates had a similar diameter of precipitation zones $(\mathrm{P}>0.05)$ that perform BSH activity. The ability of an organism's deconjugation was characterized by the presence of an opaque halo zone surround the colony that occurs caused by the liberate of free bile acids in bile salts deconjugation as reported by Sirilun et al. (2010).

Chen et al. (2010) stated that almost yeast strains isolated from cow raw milk were able to grow in the bile salt solutions during in vitro test. According to Rajkowska et al. (2012), S. cerevisiae demonstrated high resistance to synthetic bile salts $(50 \%$ sodium deoxycholate and $50 \%$ sodium cholate respectively) as well. According to Das (2016), specific and nonspecific defense mechanisms of the gut were ruled by bile salts released into the upper small intestine. Hence, bile salt is essential for the cell membranes of microorganisms made up fatty acids and lipid. The efficacy of its inhibitory effect is mainly determined by bile salt concentration. Bile tolerance was important for allowing a microorganism to survive in the intestinal tract.

The lower BSH activities of some probiotic strains used in this study may be due to low levels of $\mathrm{BSH}$ production or differences in enzyme structure. Tanaka et al. (2000) reported that the molecular weight and structure of BSH is strain dependent. On this basis, we postulate that the changes observed in BSH activities may be due to differences in the putative active sites of the BSH enzymes. The BSH secretion indicated an early important enzyme in cholesterol-lowering effect. The BSH was able to hydrolyze conjugated bile salt that could precipitate with cholesterol affirm in reducing cholesterol (Liu et al., 2012).

\section{Cholesterol Assimilation in Media}

Top four isolates with the highest precipitation zone diameters were determined for cholesterol assimilation activity. The cholesterol assimilation assay of the yeast isolates was investigated through incubation of $500 \mathrm{ppm}$ soluble cholesterol-Tween 80 in CYG for $72 \mathrm{~h}$ at $30^{\circ} \mathrm{C}$. Table 2 showed that B-18 isolate produced the highest percentage of cholesterol assimilation $(51.83 \%)$. The lower cholesterol assimilation ability observed in M-21 and M-22 strains may be due to differences in their cell wall composition that makes them unable to bind cholesterol and as a result from their lower tolerance towards sodium glycocholate and oxgall (Kimoto et al., 2002). Kluyveromyces marxianus $\mathrm{K} 1$ and $\mathrm{M} 3$ produced a high rate of cholesterol-lowering 


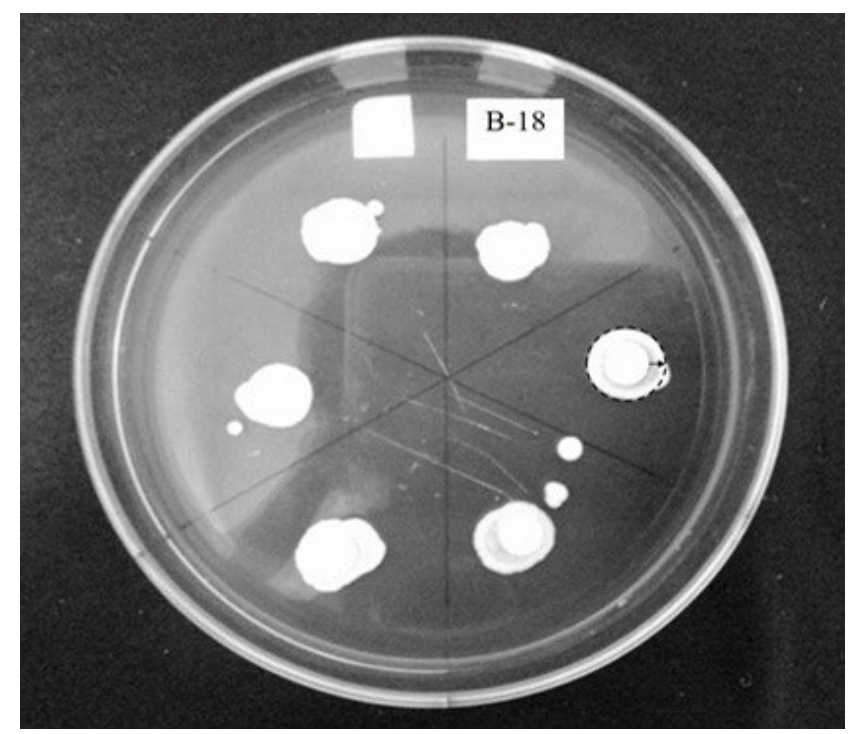

Figure 1. Detection of BSH Activity, S. cerevisiae B-18 Grown in CYG Broth (24 h) and Streaked into CYG Agar Supplemented with $0.37 \mathrm{~g} / \mathrm{L} \mathrm{CaCl}_{2}$ and $0.5 \%(\mathrm{w} / \mathrm{v})$ Taurodeoxycholic Acid (TDCA)

Table 1. Diameter Precipitation Zone of Yeast with High BSH Activity

\begin{tabular}{|c|c|c|c|}
\hline \multirow{2}{*}{ Isolate } & \multirow{2}{*}{ Host } & \multicolumn{2}{|c|}{ Media } \\
\hline & & CYG agar & CYG agar + TDCA \\
\hline A-26 & Native chicken colon & $0.41 \pm 0.11^{\mathrm{a}}$ & $0.46 \pm 0.10^{\mathrm{a}}$ \\
\hline B-18 & Javanese duck colon & $0.39 \pm 0.10^{\mathrm{a}}$ & $0.48 \pm 0.04^{\mathrm{a}}$ \\
\hline M-21 & Muscovy duck caecum & $0.48 \pm 0.09^{\mathrm{a}}$ & $0.52 \pm 0.10^{\mathrm{a}}$ \\
\hline M-22 & Muscovy duck caecum & $0.55 \pm 0.04^{\mathrm{a}}$ & $0.56 \pm 0.10^{\mathrm{a}}$ \\
\hline
\end{tabular}

Average in the same column with similar superscript shown no significant difference $(\mathrm{P}>0.05)$. A (native chicken), B (Javanese duck), M (Muscovy duck)

strains, the former rate was $68.14-70.34 \%$, the latter rate was $80.51-99.12 \%$ (Liu et al., 2012). Syal and Vohra (2013) reported that yeast isolated from traditional Indian fermented foods were able to assimilate cholesterol (57.13-88.50\%) after incubation with cholesterol at $37^{\circ} \mathrm{C}$ for $48 \mathrm{~h}$.

Psomas et al. (2003) reported that two yeast isolated from infant feces (Isaatchenkia orientalis KK5.Y.1 and S. cerevisiae KK1) and one isolate from Feta cheese (S. cerevisiae 832) were able to eliminate cholesterol from the growth medium around $96.8 \%, 88.1 \%$, and $90.4 \%$ respectively after incubation at $37^{\circ} \mathrm{C}$ for $48 \mathrm{~h}$. The cholesterollowering mechanism from the medium could be due to the assimilation of cholesterol into the cell membranes of yeasts and the linkage of cholesterol to the surface of yeast cells. $S$. cerevisiae strains indicated that yeast could eliminate cholesterol from media supplemented with cholesterol at optimum growth conditions.

Chen et al. (2010) also reported that seven yeast strain from 17 yeast strains with $\mathrm{BSH}$ activity, that is Galactomyces sp. BY1, $P$. guilliermondii BY31P, P. kudriavzevii BY10, $P$. kudriavzevii BY15, P. fermentans BY5, Y. lipolytica $\mathrm{HY} 4$, and $Y$. lipolytica $\mathrm{HJ} 10$ were potential to assimilate cholesterol from YPDCHOL broth after $72 \mathrm{~h}$ of incubation in the range of $39.8-45.5 \%$. The yeast strains $Y$. lipolytica HY4, P. kudriavzevii BY10, P. kudriavzevii BY15, 
Table 2. Cholesterol Assimilation by Yeast Isolates Grown in CYG Broth and Supplemented with Cholesterol (500 ppm)

\begin{tabular}{ccc}
\hline Isolate & $\begin{array}{c}\text { Cholesterol } \\
\text { Assimilation (ppm) }\end{array}$ & $\begin{array}{c}\text { Cholesterol } \\
\text { Assimilation (\%) }\end{array}$ \\
\hline A-26 & $99.00 \pm 8.50^{\mathrm{b}}$ & $23.06 \pm 2.80^{\mathrm{b}}$ \\
B-18 & $222.50 \pm 5.75^{\mathrm{a}}$ & $51.83 \pm 1.34^{\mathrm{a}}$ \\
M-21 & $77.33 \pm 12.85^{\mathrm{bc}}$ & $18.02 \pm 2.99^{\mathrm{bc}}$ \\
M-22 & $72.17 \pm 18.06^{\mathrm{c}}$ & $16.8 \pm 4.21^{\mathrm{c}}$ \\
\hline
\end{tabular}

Note: Average in the same column with different superscript shown a significant difference $(\mathrm{P}<0.05)$. A (native chicken), B (Javanese duck), $\mathrm{M}$ (Muscovy duck)

and $P$. fermentans BY5 as probiotics were able to assimilate cholesterol in the human intestine.

Saikia et al. (2017) described the specific mechanism of cholesterol-lowering by $S$. cerevisiae. The in vitro activity of cholesterollowering was caused by the acceptance of cholesterol in growing yeast cells. The binding of bile acids by $\beta$-glucans in the human intestine were able to eliminate in bile acid pool and improved cholesterol breakdown. Kusmiati and Dhewantara (2016) also revealed that treatment of $\beta$-glucan $(40 \mathrm{mg}$ ) from $S$. cerevisiae culture on rats significantly reduced the total cholesterol levels in liver (92.32\%) and blood plasma (63.88\%).

The mechanism of cholesterol reduction also known possessed by probiotic lactic acid bacteria (LAB). According to Lee et al. (2009) there were several mechanisms of cholesterol reduction by the activity of LAB. The first mechanism was the product of fermentation by LAB could inhibit cholesterol synthesis. The second mechanism was through the removal of bile salts through the feces, where the unconjugated bile salts would not be absorbed by the intestine and are more easily removed. This caused the more cholesterol needed to synthesize bile salts, thereby lowering cholesterol levels. The third mechanism is the ability of the LAB to bind cholesterol to prevent cholesterol absorption back to the liver.

All probiotic bacterial strains possess the varying degree of cholesterol removal capacities from the media through several mechanisms including cholesterol assimilation, cholesterol incorporated into cellular membrane, cholesterol binding to cells and also bile salt deconjugation. This implies that cholesterol removal is not only by the assimilation mechanism by growing probiotic cells but also by an adhesion mechanism to cell membranes (Miremadi et al., 2014).

\section{Identification of Selected Yeast with the Highest Cholesterol Assimilation Activity}

Characterization of yeast was based on partial genetic analysis in the ribosomal DNA D1/D2 Large Sub Units (LSU) region to determine the genus and strain. This gene was amplified using NL1 primer: 5'CATATCAATAAGCGGAGGAAAG-3' and NL4 primer: 5'-GTCCGTGTTTCAAGACGG-3`.

The DNA Data Bank of Japan/DDBJ database revealed species with a high degree of sequence similarity with the colonies that was sequenced and classified based the source of isolation. BLAST homology of 26S rRNA sequences in DDBJ site revealed that B-18 isolate was identified as $S$. cerevisiae with a length of 889 bp in DDBJ had $99 \%$ of max identity, 1122 of the max score, 1122 of the total score, $99 \%$ of query coverage, and 0.0 of E-value. The yeast was classified in the Kingdom of Fungi, Phylum of Ascomycota, Subphylum of Saccharomycotina, Order of Saccharomycetales, , Family of Saccharomycetaceae, Genus os Saccharomyces and Species of S. cerevisiae. Al-Shimmery (2011) reported that 58 yeast isolated from intestinal tracts were dominated by Saccharomyces (31.03\%).

Phylogenetic analysis of B-18 isolate by nucleotide reference from Gen Bank data in National Center for Biotechnology Information/NCBI is presented in Figure 2. Branch lengths are proportional to genetic distances (Becher et al., 1997). Bootstrap values of over $70 \%$ were shown for 1,000 replicate datasets (Coenye and Vandamme, 2003). The tree describes the relationship between nucleotide sequences from the isolate in this study with selected sequences retrieved from the GenBank database. The phylogenetic tree showed that $S$. cerevisiae $\mathrm{B}-18$ isolated from Javanese duck was closely related to $S$. cerevisiae $\mathrm{mt} 21 \mathrm{~s}$ (accession number X00149.1) based on the D1/D2 regions. The genera of yeast group other than Saccharomyces were Debaryomyces, Pichia, Torulopsis, Candida, Cryptococcus, Kluyveromyces, Williopsis and Zygosaccharomyces (Hatoum et al., 2012). The genera were seen clumped in phylogenetic trees 


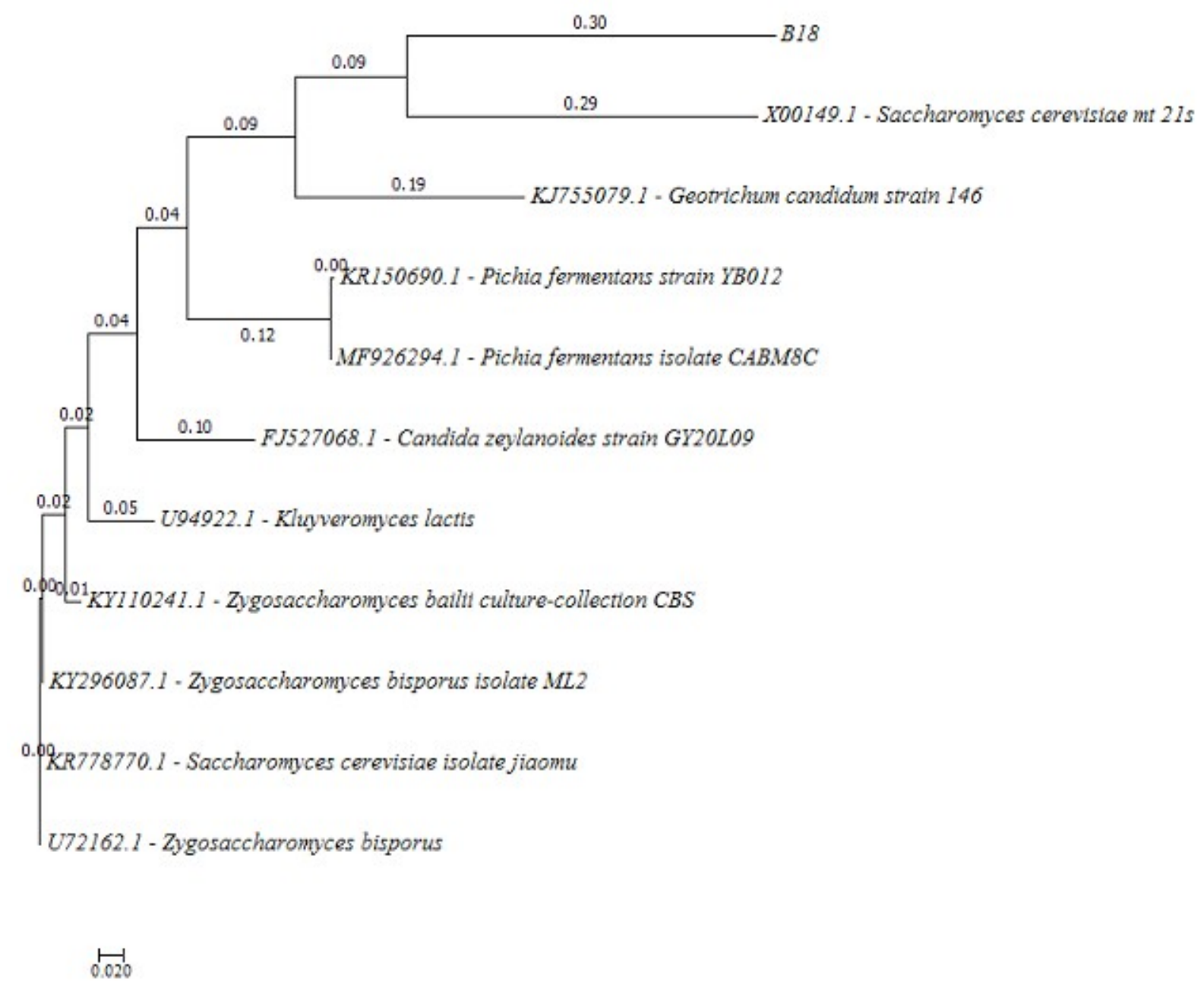

Figure 2. Phylogenetic Tree of B-18 Isolate and Yeast Constructed by a Neighbor-joining Method. The Scale Bar Represents a Sequence Divergence of $2 \%$.

(Figure 2).

$S$. cerevisiae in several studies reportedly found in human and animal gastrointestinal tracts and commonly found in food and fermented products. S. cerevisiae S10 with probiotic properties was isolated from chicken feces (Rajkowska and Kunicka-Styczyska, 2010). Five strain of $S$. cerevisiae were isolated from food samples and were showed considerable probiotic properties with survivability through the simulated gastrointestinal tract in the range of $80<$ $\%<90$ (Pennacchia et al., 2008). Another study showed that $S$. cerevisiae ARDMC1 isolated from traditional rice beer starter had cholesterol reduction capability in vitro and in vivo on rat
(Saikia et al., 2017). A study by Syal and Vohra (2013), showed that twenty yeast isolates from traditional Indian fermented foods (idli and jalebi batter) were identified as $S$. cerevisiae, Candida tropicalis, Aureobasidium sp. and P. manschuria and could assimilate from $57 \%$ up to $88.5 \%$ cholesterol. S. cerevisiae KK1 isolated from infant feces and $S$. cerevisiae 832 isolated from Feta cheese were have capabilities to assimilate cholesterol $(>83.4 \%)$ after incubation at $37^{\circ} \mathrm{C}$ for 24 h (Psomas et al., 2003). S. cerevisiae 1R27 isolated from Palm Raffia (Raffia mambillensis) Wine indicated cholesterol-lowering properties in vivo with the capacity to adhere to epithelial intestine-derived cells, decreased lipidemia (total 
cholesterol, triglyceride, and LDL), and increased HDL (Ngongang et al., 2017)

\section{CONCLUSION}

Yeast strain isolated from the gastrointestinal tract of Indonesian native chicken (Gallus javanicus), Javanese duck (Anas javanicus) and Muscovy duck (Anas moschata) had the cholesterol assimilation activity. Yeast B-18 isolated from the colon of Javanese duck was identified as Saccharomyces cerevisiae and produced the highest percentage to assimilate cholesterol $(51.83 \%)$. Phylogenetic tree analysis performed that B-18 isolate was closely related to Saccharomyces cerevisiae $\mathrm{mt} 21 \mathrm{~s}$. It could be concluded that Saccharomyces cerevisiae B-18 may serve potential isolate for assimilating cholesterol.

\section{ACKNOWLEDGMENTS}

Authors would like to thanks to the technician Madina Nurohmah for supporting this experiment.

\section{REFERENCES}

Abbas, M.S., S.N. Yassein, and J.M. Khalaf. 2017. Isolation and identification of some important mycological isolates from dropping of birds in Baghdad. J. Entomol. Zool. Stud. 5(3): 671-673.

Afriani, H. 2003. Pengaruh Dosis Kultur Bacillus sp. dan Saccharomyces cerevisiae sebagai Probiotik terhadap Performa, Kadar Lemak dan Kolesterol Karkas Ayam Broiler. Tesis. Program Pascasarjana Universitas Padjadjaran, Bandung.

Al-Shimmery, F.A. 2011. Investigation on The Occurrence of Yeast Species in the Digestive Tracts of Broiler. Proceedings. The $1^{\text {st }}$ International Conferences, Collage of Agricultural, University of Babylon, Iraq. P. 37-42.

Altschul, S.F., W. Gish, W. Miller, E.W. Myers, and D.J. Lipman. 1990. Basic Local Alignment Search Tool. J. Molecular Biology 215: 403-410.

Arbeli, Z. and C.L. Fuentes. 2007. Improved puri ccation and PCR ampliccation of DNA from environmental samples. Federation of Eoropean Microbiological Society (FEMS) Microbiol. Lett. 272: 269-275.
Begley, M., C. Hill, and C.G.M. Gahan. 2006. Bile salt hydrolase activity in probiotics. Appl. Environ. Microbiol. 72(3):17291738.

Brilhante, R.S.N., D.S.C.M. Castelo-Branco, G.D.P. Soares, D.J. Astete-Medrano, A.J. Monteiro, R.A. Cordeiro, J.J.C. Sidrim, and M.F.G. Rocha. 2010. Characterization of the gastrointestinal yeast microbiota of cockatiels (Nymphicus hollandicus): a potential hazard to human health. J. Med. Microbiol. 59: 718-723.

Cheong C., K. Wackerbauer, M. Beckmann, K.H. Jang, and S.A. Kang. 2008. Effect of cultivation conditions on trehalose content and viability of brewing yeast following preservation via filter paper or lyophilization methods. Biotechnol Bioprocess. Eng. 13:690-696.

Chen, L., Ma, Y., Maubois, J., He, S., Chen, L. and Li, H. 2010. Screening of potential probiotic yeasts strains from raw milk to assimilate cholesterol. Dairy Sci. Tech. 90:537-548.

Choe, J.H., K. Nam, S. Jung, B. Kim, H. Yun, and C. Jo. 2010. Differences in the quality characteristics between commercial Korean native chickens and broilers. Korean J. Food Sci. Anim. Resour. 30(1): 13-19.

Cobos, M.A., A.L. de Coss, N.D. Ramirez, S.S. Gonzales, and R.F. Cerrato. 2011. Pediococcus acidilactici isolated from the rumen of lambs with rumen acidosis, $16 \mathrm{~S}$ rRNA identification and sensibility to monensian and lasalocid. Res. Vet. Si. 90: $26-30$.

Cohort. 2008. CoSTAT Version 6.400. Cohort Software 798. Lighthouse Ave, Monterey, USA.

Das, N. 2016. A review on probiotic yeast strains from food and environmental origin. Res. J. Pharm. Biol. Chem. Sci.7(6): 95-99.

FAO/WHO. 2002. Guidelines for the evaluation of probiotics in food, London, Ontario, Canada.

Gilliland, S.E., C.R. Nelson, and C. Maxwell. 1985. Assimilation of cholesterol by Lactobacillus acidophilus. Appl. Environ. Microbiol. 49(2): 377-381.

Gomez, K.A. and A.A. Gomez. 2007. Statistical Procedures for Agricultural Research $2^{\text {nd }}$ Ed. UI Press, Jakarta.

Hatoum, R., S. Labrie and I. Fliss. 2012. Antimicrobial and probiotic properties of 
yeasts: from fundamental to novel applications. Front. Microbiol. 3(421): 1 12.

Ismoyowati dan Widiyastuti, T. 2003. Fat and cholesterol of breast and thighs of various local poultry. J. Anim. Prod. 5(2): 79-82.

Jaturasitha, S., T. Srikanchai, M. Kreuzer, and M. Wicke. 2008. Differences in carcass and meat characteristics between chicken indigenous to Northern Thailand (BlackBoned and Thai Native) and imported extensive breeds (Bresse and Rhode Island Red). Poult. Sci. 87(1): 160-169.

Kimoto, H., S. Ohmomo, and T. Okamoto. 2002. Cholesterol removal from media by lactococci. J. Dairy Sci. 85: 3182-3188.

Kurtzman, C.P. and C.J. Robnett. 1998. Identification and phylogeny of ascomycetous yeasts from analysis of nuclear large subunit (26s) ribosomal DNA partial sequences. Antonie van Leeuwenhoek. 73(4): 331-371.

Kusmiati and F.X. Dhewantara. 2016. Cholesterol-lowering effect of beta glucan extracted from Saccharomyces cerevisiae in rats. Sci. Pharma. 84(1): 153-165

Lim J.H., Y.K So, K.L. Wan. 2004. Isolation of lactic acid bacteria from human intestine for probiotic use. J. Vet. Sci.5(4): 391-395.

Liu, H., Y. Xie, L. Xiong, R. Dong, C. Pan, G. Teng, H. Zhang. 2012. Effect and mechanism of cholesterol-lowering by Kluyveromyces from Tibetan Kefir. Adv. Mater. Res. 343-344: 1290-1298.

Miremadi F., M. Ayyash, F. Sherkat, L. Stojanovska. 2014. Cholesterol reduction mechanisms and fatty acid composition of cellular membranes of probiotic Lactobacilli and Bifidobacteria. J. Funct. Foods 9: 295-305.

Ngongang E.F.T, B. Tiencheu, B.T. Fossi, G. T. Nchanji, D.M. Shiynyuy, F.T. Mbiapo and Z. N. François. 2017. Isolation and identification of cholesterol lowering probiotic yeast from palm raffia (Raffia mambillensis) wine. Journal of Advances Biology and Biotechnology (JABB). 11(2): $1-17$.

Pennacchia, C., G. Blaiotta, O. Pepe and F. Villani. Isolation of Saccharomyces cerevisiae strains from different food matrices and their preliminary selection for a potential use as probiotics. J. Appl. Microbiol. 105: 1919-1928.
Psomas E.I., D.J. Fletouris, E. LitopoulouTzanetaki, and N. Tzanetakis. 2003. Assimilation of cholesterol by yeast strains isolated from infant feces and Feta cheese. J. Dairy. Sci. Technol. 86: 3416-3422.

Rajkowska, K., A. Kunicka-StyczyBska, and A. Rygal'a. 2012. Probiotic activity of Saccharomyces cerevisiae var. boulardii against human pathogens. J. Food Technol. Biotechnol. 50: 230-236.

Rajkowska, K. and A. Kunicka-Styczyñska. 2010. Probiotic properties of yeasts isolated from chicken feces and kefirs. Pol. J. Microbiol. 59(4): 257-263

Roto, S.M., P.M. Rubinelli, and S.C. Ricke. 2015. An introduction to the avian gut microbiota and the effects of yeast based prebiotic-type compounds as potential feed additives. Front. Vet. Sci. 2:28: 1-19.

Saikia, D., A. K. Manhar, B. Deka, R. Roy, K. Gupta, N.D. Namsa, P. Chattopadhyay, R. Doley, and M. Mandal. 2017. Hypocholesterolemic activity of indigenous probiotic isolate Saccharomyces cerevisiae ARDMC1 in a rat model. J. Food. Drug Anal. http://dx.doi.org/10.1016/j.jfda.2016.12.017

Sourabh, A., S.S. Kanwar, and O.P. Sharma. 2015. Screening of indigenous yeast isolates obtained from traditional fermented foods of Western Himalayas for probiotic attributes. J. Yeast. Fungal. Res. 2(8): 117126.

Sirilun, S., C. Chaivayat, D.K and P. Luxananni. 2010. Characterisation of non human origin probiotic Lactobacillus plantarum with cholesterol-lowering property. Afr. J. Microbiol. Res. 4(10): 994-1000.

Syal, P. and A. Vohra. 2013. Probiotic potential of yeasts isolated from traditional Indian fermented foods. Int. J. Microb. Res. 5(2): 390-398.

Tanaka, H., H. Hashiba, J. Kok, and I. Mierau, I. 2000. Bile salt hydrolase of Bifidobacterium longum - Biochemical and genetic characterization. Appl. Environ. Microbiol. 66: 2502-2512.

Tomaro-Duchesneau C., M.L. Jones, D. Shah, P. Jain, A. Saha, and S. Prakash. 2014. Cholesterol assimilation by Lactobacillus probiotic bacteria: an in vitro investigation. BioMed Res. Int. 1-9

Tomičić, Z.M, R.R. Čolović, I.S. Čabarkapa, D.M. Vukmirović, O.M. Đuragić, and R.M. 
Tomičić. 2016. Beneficial properties of probiotic yeast Saccharomyces boulardii. Food Feed Res. 43(2): 103-110.

Wang, Y., C. Lehane, K. Ghebremeskel, and M.A. Crawford. 2009. Modern organic and broiler chickens sold for human consumption provide more energy from fat than protein. Public. Health. Nutr. 13(3): 400-408. 